DOI: https://doi.org/10.47405/mjssh.v6i3.688

\begin{tabular}{|c|c|}
\hline & Malaysian Journal of Social Sciences and Humanities (MJSSH) \\
\hline 32 & Volume 6, Issue 3, March 2021 \\
\hline 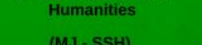 & e-ISSN : 2504-8562 \\
\hline & $\begin{array}{l}\text { Journal home page: } \\
\text { www.msocialsciences.com }\end{array}$ \\
\hline
\end{tabular}

\title{
Kerelevanan Aplikasi Kaedah Protokol Pemikiran Verbal (Think-Aloud Protocols) dalam Terjemahan: Analisis Corak Kajian Lepas
}

\author{
Lubna Abd Rahman', Arnida A. Bakar ${ }^{1}$ \\ ${ }^{1}$ Fakulti Pengajian Bahasa Utama, Universiti Sains Islam Malaysia (USIM) \\ Correspondence: Lubna Abd Rahman (lubna@usim.edu.my)
}

\begin{abstract}
Abstrak
Protokol Pemikiran Verbal atau Think-Aloud Protocols (TAPs), merupakan salah satu kaedah saintifik yang lazimnya diguna pakai dalam kajian yang melibatkan proses kognitif atau pemikiran manusia yang bertujuan untuk mengenal pasti apa yang berlegar dalam minda subjek kajian apabila diberikan tugasan tertentu berkaitan tajuk kajian. Subjek akan menyuarakan pendapat atau pemikiran mereka secara verbal semasa tugasan tersebut dilakukan atau setelah selesai tugasan. Melalui TAPs, data atau rumusan mengenai isu yang ditimbulkan dalam kajian dapat dikenal pasti. Kaedah ini dilihat sesuai diaplikasikan dalam bidang terjemahan terutamanya apabila mengkaji proses terjemahan. Kajian ini menggunakan kaedah penyelidikan kualitatif. Data dikumpulkan daripada aplikasi carian Google dan Google Scholar melalui kaedah 'Systematic Literature Review' dengan melakukan analisis ke atas bahan literatur iaitu artikel jurnal antara tahun 2011-2020 bagi menyoroti kajian lepas mengenai aplikasi TAPs dalam terjemahan. Hanya 32 artikel penulisan didapati bertepatan dengan tujuan dan kaedah kajian ini. Data yang diperoleh dianalisis secara deskriptif dengan melihat kepada objektif kajian bagi menghasilkan suatu gambaran yang menyeluruh berkaitan penggunaan TAPs dalam kajian terjemahan. Kajian ini mengklasifikasikan data kepada tiga corak kajian yang mengguna pakai kaedah TAPs untuk mengkaji pelbagai isu terjemahan seperti isu proses dan strategi terjemahan, proses kognitif, tingkah laku dan kecekapan dalam terjemahan serta isu-isu lain. Hasil dapatan ini menunjukkan bahawa aplikasi TAPs dilihat masih relevan dan menjadi pilihan penyelidik untuk mengkaji isu yang melibatkan proses pemikiran, meski pun terdapat sesetengah pihak yang meragui ketepatan aplikasi kaedah ini dalam mengkaji pemikiran manusia.
\end{abstract}

Kata kunci: Think-Aloud Protocols, terjemahan, Systematic Literature Review, corak, kajian lepas

\section{The relevance of the Use of Think-Aloud Protocols (TAPs) in Translation: The analysis on Trends of Past Studies}

\begin{abstract}
Think-Aloud Protocols (TAPs), is one of the most used scientific methods in studies involving cognitive processes or human thinking aimed at identifying what is hovering in the minds of subjects in a study when given specific related tasks of a research topic. Subjects will voice their opinions or thoughts verbally during the task or after the task is completed. Through TAPs, data or summaries on issues raised in the study can be identified. This method is seen as suitable to be applied in the field of translation, especially when studying the translation process. This study employs qualitative research method. Data were collected from Google and Google Scholar search engines through the 'Systematic Literature Review' method by analyzing literature materials, namely journal articles between 2011-
\end{abstract}


2020 to highlight trends of the previous studies on the use of TAPs in translation. It was found that only 32 articles were acceptable and relevant to the objective of this study. The data obtained were analyzed descriptively by highlighting the objectives of the study to produce a comprehensive picture related to the use of TAPs in translation studies. This study classifies the data into three trends of past studies which discussed various translation issues such as translation process and strategies issues, cognitive processes, behaviour and competence in translation as well as other issues. These findings indicate that the use of TAPs is seen as still relevant and chosen by researchers to study issues involving thought processes, although there are doubts regarding the applicability of TAPs in studying human thinking.

Keywords: Think-Aloud Protocols, translation, Systematic Literature Review, trends, past studies

\section{Pengenalan}

Protokol Pemikiran Verbal, yang lebih dikenali dalam kalangan penyelidik sebagai Think-Aloud Protocols (TAPs) ${ }^{1}$, telah diguna pakai secara meluas dalam bidang kajian yang melibatkan pemikiran dan minda manusia untuk memperoleh jawapan atau solusi kepada isu atau permasalahan yang timbul. Melalui TAPs, subjek akan menterjemah pemikiran, perasaan dan pendapat mereka secara verbal, ketika mereka berinteraksi dengan bahan tugasan yang disediakan (Zaleha, 2004). Antara bidang yang sering kali menjadikan TAPs sebagai kaedah kajiannya ialah bidang psikologi dan pendidikan. Dalam pendidikan lazimnya TAPs digunakan secara meluas untuk mendapatkan data berkaitan dengan isu pembelajaran dan kemahiran bahasa seperti membaca dan menulis, sama ada dalam pembelajaran bahasa pertama atau bahasa kedua (Noor Aina \& Zaleha, 2005). Kaedah ini turut diaplikasikan oleh penyelidik dalam bidang terjemahan bermula pada kurun ke-20 kerana terjemahan berkait rapat dengan bahasa. TAPs diguna pakai sebagai satu wasilah untuk mengakses minda penterjemah dalam mengenalpasti strategi yang digunakan atau masalah yang dihadapi semasa proses terjemah sedang berlaku (Bernardini, 2001).

Eftekhary dan Aminizadeh (2012) pula menyatakan bahawa kajian tentang pembinaan serta proses minda secara umumnya dan proses terjemahan secara khususnya telah menjadi fokus penyelidikan sejak tiga dekad lalu. Proses kognitif manusia, khususnya dalam terjemahan boleh dikaji dalam pelbagai cara seperti memantau tindak balas terhadap rangsangan dan menganalisis kesalahan dan hasil tugasan. Analisis Protokol Pemikiran Verbal atau TAPs Analysis dalam bidang pengajian terjemahan telah bermula di Eropah pada lewat tahun 1980-an. Persoalan yang dibangkitkan adalah apa sebenarnya yang berlaku apabila seseorang melakukan aktiviti menterjemah. Analisis ini melibatkan proses ketika menterjemah, dan tidak melibatkan produk atau hasil terjemahan. Apa yang berlegar di dalam kotak fikiran seorang penterjemah (otak dikiaskan seperti black box) ketika proses menterjemah suatu teks dijadikan asas kajian atau analisa bagi protokol pemikiran verbal. Melalui analisis ini, satu penjelasan dan pendekatan dapat dicapai bagi mengetahui proses yang terlibat ketika terjemahan dibuat (Kussmaul \& Tirkkonen-Condit, 1995).

Penulis mendapati kaedah TAPs banyak diguna pakai dalam mengkaji isu terjemahan. Ini secara tidak langsung menunjukkan bahawa aplikasi kaedah ini masih relevan dalam sesuatu kajian termasuklah terjemahan, walaupun kedapatan pendapat yang mengkritik asas teori dan metode TAPs (Kumar, 2005). Lantaran itu, penulisan ini dilakukan bertujuan untuk menyorot kajian-kajian lepas terkini tentang aplikasi TAPs dalam bidang terjemahan dalam abad ke-21, iaitu antara tahun 2011 hingga 2020, untuk memperlihatkan kerelevanan aplikasi kaedah ini dalam bidang terjemahan dengan mengkaji tujuan kaedah ini diguna pakai dalam bidang tersebut, seterusnya mengetengahkan corak kajian berkaitan tajuk ini.

\footnotetext{
${ }^{1}$ Penulis akan menggunakan singkatan istilah Bahasa Inggeris ia itu TAPs sepanjang penulisan memandangkan istila h ini lebih dikenali dan digunakan secara meluas.
} 


\section{Sorotan Literatur}

Think-Aloud Protocol (TAPs), yang diterjemahkan ke bahasa Melayu sebagai Protokol Pemikiran Verbal, ialah satu kaedah atau teknik yang mana subjek kajian melaporkan atau menyuarakan pendapat, pemikiran atau perasaan mereka secara verbal semasa berinteraksi dengan tugasan yang diberikan atau selepas tugasan itu selesai. Melalui kaedah ini maklumat diperolehi dapat menyelesaikan masalah kognitif (Elizabeth, 2003; Zaleha, 2004; Kumar, 2005; Güss, 2018, Hulin, 2019).

TAPs dikritik hebat oleh segelintir sarjana kajian behaviorisme kerana menganggap proses kognitif, seperti memori, tidak boleh dikaji secara saintifik. Namun, salah anggap ini dapat dibuktikan oleh sarjana bidang psikologi kognitif, yang telah membuktikan melalui kajian mereka bahawa TAPs merupakan satu kaedah saintifik dan seterusnya diguna pakai secara meluas dalam pelbagai bidang seperti bidang psikologi, kaunseling, pendidikan, pengkomputeran, kejuruteraan perisian, pengurusan perniagaan, undang-undang dan bidang-bidang lain yang menjalankan kajian berteraskan kognitif. Ini menunjukkan bahawa kaedah ini adalah sesuai diaplikasikan, terutamanya dalam mengkaji cara manusia berfikir untuk menyelesaikan masalah (Güss, 2018).

TAPs melibatkan perkaitan antara pengujaran dan proses kognitif yang sedang berlaku, iaitu dengan menterjemahkan pemikiran bukan verbal dalam bentuk verbal. Terdapat dua bentuk kaedah bagaimana pemikiran verbal dan proses kognitif dalam TAPs berlaku. Yang pertama ialah laporan verbal serentak dan kedua ialah laporan retrospektif (Ericsson \& Simon, 1993). Dalam laporan verbal serentak, proses pemikiran berlaku seiring dengan pengujaran semasa subjek berinteraksi dengan tugasan yang diberikan. Oleh itu, maklumat yang diberikan adalah secara langsung dan menurut urutan pemikiran. Manakala dalam laporan restrospektif pula, proses kognitif mengambil masa untuk usaha untuk memahami dan memperoleh maklumat daripada tugasan dan pengujaran akan dilakukan selepas itu (Ericsson \& Simon, 1993; Kumar, 2005; Noor Aina \& Zaleha, 2005).

Kaedah ini dikatakan sesuai sekali diguna pakai dalam kajian yang melibatkan aktiviti berasaskan bahasa kerana mempunyai asas teori yang kukuh dan mampu menghasilkan sumber data yang sahih mengenai pemikiran subjek kajian (Elizabeth, 2003). Oleh itu, penulis mendapati bahawa kaedah TAPs lazimnya diguna pakai dalam kajian mengenai pembelajaran dan kemahiran bahasa sebagai kaedah untuk memperoleh data berkaitan tajuk.

Namun, penyelidik di Barat telah mengorak langkah untuk mengaplikasikan kaedah ini dalam bidang terjemahan lewat 1980-an, iaitu dipelopori oleh Ericsson dan Simon pada tahun 1984. Secara umumnya, kaedah ini, yang asalnya digunakan dalam bidang psikologi, digunakan secara meluas dalam bidang terjemahan kerana dipercayai boleh menyingkap proses pemikiran minda manusia. Kaedah ini juga menjadi salah satu kaedah empirikal yang digunakan untuk mengkaji aspek psikologi dalam proses terjemahan (Kussmaul \& Tirkkonen-Condit, 1995; Gheorghită, 2012).

Sebelum TAPs mula diguna pakai dalam bidang terjemahan, kajian-kajian lepas yang berkisar tentang terjemahan lebih tertumpu kepada produk terjemahan berbanding proses terjemahan. Tetapi, apabila TAPs mula diaplikasikan secara meluas ke atas proses terjemahan, kajian demi kajian telah dijalankan oleh penyelidik, terutamanya penyelidik Barat, untuk mendapatkan solusi kepada permasalahan yang dihadapi oleh penterjemah semasa melakukan penterjemahan. Melalui TAPs, subjek kajian diminta menceritakan secara verbal apa yang mereka fikirkan sewaktu melakukan tugasan yang diberikan. Maklumat tersebut akan direkod menggunakan pelbagai medium rakaman, di transkrip dan dianalisis (Kussmaul \& Tirkkonen-Condit, 1995).

Oleh kerana terjemahan juga dianggap sebagai satu fenomena memproses dan menyimpan maklumat dalam minda manusia yang boleh disuarakan, TAPs dikatakan menjadi salah satu cara paling berkesan untuk mendedahkan proses terjemahan (Bernardini, 2001; Hulin, 2019). Oleh itu, tidak hairanlah ramai penyelidik menggunakan kaedah ini untuk mengkaji apa yang berlegar di minda subjek kajian semasa proses terjemahan. Dalam terjemahan, TAPs membenarkan penyelidik menjalankan analisis tertentu ke atas pelbagai bentuk proses terjemahan seperti peringkat, prosedur, unit pemprosesan dan peranan serta interaksi antara teks sumber dan teks sasaran. (Dechert \& Sandrock, 1986 dalam Gurdial Singh, 2002). 
Pada mulanya, kajian terjemahan yang mengguna pakai kaedah TAPs lebih memfokuskan dua perkara utama; pertama ialah mengecam serta mengklasifikasikan strategi terjemahan dan kedua ialah menyelidiki perbezaan antara strategi penterjemah profesional dan amatur (Bernardini, 2001). Namun, penulis mendapati bahawa aplikasi TAPs tidak hanya terhad dalam mengkaji kedua-dua perkara itu sahaja, malah menjangkaui proses terjemahan yang lain. Oleh itu, melalui kajian ini penulis cuba untuk mengenal pasti corak kajian lepas yang mengguna pakai TAPs dalam bidang terjemahan melalui tujuan atau fokus kajian tersebut.

\section{Metod Kajian}

Kajian ini mengguna pakai kaedah SLR yang bersifat kualitatif dan dianalisis secara deskriptif, bertujuan melihat dengan jelas corak kajian lepas mengenai aplikasi TAPs dalam bidang terjemahan dalam dekad kedua abad ke-21, iaitu antara tahun 2011-2020. Kaedah Sorotan Literatur Sistematik atau Systematic Literature Review (SLR) dibuktikan sesuai untuk diterapkan oleh penyelidik dalam pelbagai bidang untuk mengenal pasti corak (trend atau pattern) dalam kajian yang telah dilaksanakan (Shuhairy, 2019).

Kaedah SLR ini lazimnya dicadangkan dalam kajian bidang perubatan dan sains kesihatan (Armstrong et al, 2007; Liberati et al, 2009), namun telah diperkembangkan dalam kajian sains sosial dan kemanusiaan oleh ramai penyelidik selepas didapati bahawa kaedah ini juga sesuai diaplikasikan dalam bidang tersebut. SLR membantu penulis mengesan bahan literatur yang tepat berdasarkan objektif kajian.

Dalam kajian ini, aplikasi carian atau pangkalan data Google dan Google Scholar digunakan untuk melakukan pencarian artikel memandangkan kedua-dua aplikasi carian tersebut dapat membekalkan bahan literatur dalam pelbagai bentuk seperti buku, tesis, artikel jurnal dan prosiding. Walau bagaimanapun, kajian ini hanya memilih artikel jurnal sebagai bahan literatur untuk dikaji.

Beberapa kata kunci digunakan untuk melakukan carian bahan literatur, iaitu: translation, Think-Aloud Protocols dan TAPs. Tempoh kajian yang ditetapkan adalah tertumpu dari tahun 2011 hingga 2020, iaitu hanya artikel penulisan dalam dekad mutakhir. Prinsip SLR ini membantu kajian dalam mendapatkan sejumlah bahan literatur yang menepati objektif kajian.

Setelah melepasi kriteria pencarian dalam kaedah SLR seperti kelayakan dan penyisihan (Jadual 1), hanya 32 dokumen sahaja berkaitan dengan aplikasi TAPs dalam kajian terjemahan dapat diakses dan diterima untuk dianalisis. Satu analisis deskriptif dijalankan dengan memfokuskan objektif kajian untuk mengupas corak tujuan kajian tersebut dijalankan.

Jadual 1: Kriteria kelayakan dan penyisihan

\begin{tabular}{lll}
\hline Kriteria & Kelayakan & Penyisihan \\
\hline Jenis Literatur & Artikel jurnal & $\begin{array}{l}\text { Buku, bab dalam buku, artikel seminar } \\
\text { dan prosiding, ulasan literatur }\end{array}$ \\
Bahasa & Bahasa Inggeris & Selain bahasa Inggeris \\
Bidang & Terjemahan & Selain terjemahan \\
Tempoh Masa & $2011-2020$ & Selain 2011-2020 \\
Liputan Negara & Seluruh Dunia & Tiada \\
\hline
\end{tabular}




\section{Hasil Kajian}

Berdasarkan data yang telah diperoleh melalui kaedah Sistematic Literature Review, terdapat 32 buah artikel yang telah dikenal pasti mempunyai kaitan dengan aplikasi Prosedur Pemikiran Verbal atau Think-Aloud Protocol (TAPs) dalam bidang terjemahan. Dalam erti kata lain, kajian ini mengguna pakai TAPs sebagai kaedah utama atau salah satu kaedah untuk menyelidiki subjek kajian dalam isu berkaitan terjemahan.

Daripada jumlah tersebut, penulis mengklasifikasikannya kepada tiga corak kajian: pertama: kajian berkaitan proses dan strategi terjemahan; kedua: berkaitan proses kognitif, tingkah laku dan kecekapan dalam terjemahan dan ketiga: isu-isu lain. Kupasan untuk setiap corak kajian adalah berdasarkan jadual yang mengandungi maklumat objektif kajian seperti di bawah.

\section{Corak 1: Isu Berkaitan Proses Dan Strategi Terjemahan}

Proses terjemahan lazimnya melibatkan susunan peringkat dan tatacara kerja untuk menghasilkan produk terjemahan. Dalam proses ini, penterjemah perlu membuat keputusan untuk memilih pendekatan, prosedur atau strategi yang bersesuaian dengan keperluan tugasan penterjemahan yang dilakukan.

Dalam erti kata lain, proses terjemahan ini ialah tindakan atau proses yang dilalui oleh penterjemah untuk memindahkan maklumat daripada teks sumber kepada teks sasaran (Goh, 2013; Hasuria, 2013). Di sinilah penterjemah perlu memahami mesej dan makna teks sumber, seterusnya memilih pendekatan, kaedah atau strategi yang sesuai untuk menyampaikan mesej teks sumber kepada pembaca sasaran.

Aplikasi kaedah TAPs dilihat sesuai untuk mengkaji proses dan strategi terjemahan yang diamalkan oleh penterjemah. Oleh itu, data dalam Jadual 2 yang berikut menunjukkan bilangan kajian yang mengaplikasikan kaedah TAPs untuk mengkaji isu berkaitan:

Jadual 2: Isu berkaitan proses dan strategi terjemahan

\begin{tabular}{|c|c|c|c|c|}
\hline No & Tahun & Penulis & Tajuk Kajian & Objektif Kajian \\
\hline 1 & 2011 & Sanjun Sun & $\begin{array}{lr}\text { Think-Aloud-Based } \\
\text { Translation } \quad \text { Process } \\
\text { Research: } \quad \text { Some } \\
\text { Methodological } & \\
\text { Considerations } & \end{array}$ & $\begin{array}{l}\text { This paper deals with } \\
\text { methodological issues in think- } \\
\text { aloud-based translation process } \\
\text { research from two perspectives: } \\
\text { theoretical and practical. }\end{array}$ \\
\hline 2 & 2012 & $\begin{array}{l}\text { Yali Zhou, Yan } \\
\text { Lin }\end{array}$ & $\begin{array}{l}\text { Probe into Translation } \\
\text { Process Based on Think- } \\
\text { Aloud Protocols }\end{array}$ & $\begin{array}{l}\text { This paper tries to explore the } \\
\text { translation process of the student } \\
\text { translator while translating. }\end{array}$ \\
\hline 3 & 2012 & $\begin{array}{l}\text { Ali Asghar } \\
\text { Eftekhary, } \\
\text { Shayesteh } \\
\text { Aminizadeh }\end{array}$ & $\begin{array}{l}\text { Investigating the Use of } \\
\text { Thinking Aloud Protocols } \\
\text { in Translation of Literary } \\
\text { Texts }\end{array}$ & $\begin{array}{l}\text { The purpose of the present study } \\
\text { was to investigate the strategies } \\
\text { senior translation students of } \\
\text { Islamic Azad University, Bandar } \\
\text { Abbas Branch apply while } \\
\text { translating literary texts using } \\
\text { Thinking Aloud Protocols. }\end{array}$ \\
\hline 4 & 2012 & $\begin{array}{l}\text { Elena } \\
\text { Gheorghită }\end{array}$ & $\begin{array}{l}\text { Using Think-Aloud } \\
\text { Protocols to Investigate } \\
\text { the Translation Process: } \\
\text { Methodological Aspects }\end{array}$ & $\begin{array}{l}\text { The aim of this paper has been to } \\
\text { discuss some methodological } \\
\text { issues relating to the use of } \\
\text { think-aloud protocols in process- } \\
\text { oriented translation studies }\end{array}$ \\
\hline
\end{tabular}


5

2012 Yali Zhou \&
Xuefang Jiang

Base

An Investigation on

Based on Think-aloud Protocols

6

2013 Mahsa

Gandomkar, Amin Karimnia

An Investigation into Iranian Students'

Translation Strategies

Based on Gerloff's Model of Think-Aloud

2014 Julia Eka Rini

The Role of Culture in

Translation

Through

Process

Protocols

8

2014 Serhii Zasiekin

Literary

Translation

Universals:

Think-Aloud

Psycholinguistic Study of

The Novice Translator's

Common Choices

9

2015 Kutay Uzun

How

Translation-

Interpretation Students

Process Cultural Texts:

A Think-Aloud Protocol Analysis"

10
Translation

Comparison

Professional and Amateur

Raden

Arief

Nugroho
Translators

Translating Wiki Thukul's

Poem "Apa Guna"
Process

Between

in

's

an

The main concern of this paper is to explore the translation strategies employed by Chinese participants when they fulfil both E-C and C-E translation tasks.

The present study tended to investigate different strategies applied by Iranian B.A students of translation.

This study investigates two aspects; first, the translation process of culture-bound words and second, the strategies taken by two translators.

The paper outlines the study of translation $S$-universals and is based both on the psycholinguistic model of literary translation, which combines two approaches to language organization in today's neuroscience - cognitivism and connectionism, and on the experimental data that demonstrate its validity. A 'think aloud protocol' (TAP) analysis was used to explore the ways in which the meaning of the original text was reconstructed in the target text by the novice translators.

The present study focuses on revealing translation students' cultural text processing strategies

This study aims to compare the translation process including the problems and strategies in translating the source text and the quality of the translated text between professional and amateur translators. 
11

\section{5} Luo Mengyan
Zhao Yushan
Factors Influencing the Choice of Translation Strategies Based on Think-Aloud Protocols
12

\section{Sareh}

Fereydouni, Amin Karimnia

Process-oriented Translation Studies: Case Study Based on Lörscher's Model
In this paper, the translation strategies are investigated based on think-aloud protocols, which aims to discuss the main factors influencing the translator's choice of strategies, such as types of source text, purpose of translation, ideology, translator's way of thinking and their aesthetic orientation.

The present study aimed at A investigating Iranian M.A on students of translation uses of TAPs strategies while translating a text from English into Persian.

13

2017 Kulwindr Kaur $\mathrm{a} / \mathrm{p} \quad$ Gurdial Singh

A Think-Aloud Protocol of the translation process of a scientific text from English to Malay

to investigate whether the direct (memory, cognitive and compensation) and indirect (metacognitive, affective and social) language learning strategies put forward by Oxford (1990) were used during the translation process.

to identify the strategies that were used the most in the translation process.

to investigate the problems faces while translating and how they were overcome.

142019 Hulin Zhao A Quantitative and The article adopts a mixed Qualitative Analysis of approach to the contrastive Strategy of Translation analysis of Chinese-English (CBased on TAPS
$E)$ and English-Chinese (E-C) translation strategy based on think-aloud protocols. It is hoped that research findings can shed some light on the translation strategy research and education of student translators' translation competence.

Kajian terjemahan menggunakan kaedah TAPs yang menyelidiki proses terjemahan khususnya berkaitan strategi terjemahan dilihat sebagai corak kajian terbesar memandangkan jumlah penulisan yang dihasilkan agak banyak.

\section{Corak 2: Isu Berkaitan Proses Kognitif, Tingkah Laku Atau Kecekapan Dalam Terjemahan}

Kajian ini juga menemukan 11 kajian lepas dalam bidang terjemahan yang membincangkan isu berkaitan proses kognitif dalam pelbagai aspek semasa amalan penterjemahan seperti membuat keputusan dan menyelesaikan masalah, selain kajian terhadap tingkah laku atau kecekapan dalam 
penterjemahan. Semua kajian mengaplikasi TAPs sebagai satu atau salah satu kaedah untuk mencari jawapan kepada permasalahan yang dikaji.

Jadual 3: Isu berkaitan proses kognitif, tingkah laku atau kecekapan dalam terjemahan

\begin{tabular}{|c|c|c|c|c|}
\hline$\overline{\text { Bil }}$ & Tahun & Penulis & Tajuk Kajian & Objektif Kajian \\
\hline 1 & 2012 & $\begin{array}{l}\text { Nalan Kiziltan, } \\
\text { Rita Bennett, } \\
\text { Julia Boyd }\end{array}$ & $\begin{array}{lr}\text { Translation } & \text { Problems of } \\
\text { Intermediate } & \text { Italian } \\
\text { Learners of } & \text { English in } \\
\text { Using } & \text { Bilingual } \\
\text { Dictionaries } & \end{array}$ & $\begin{array}{l}\text { This study aims at } \\
\text { understanding what goes on in } \\
\text { the translator's mind, } \\
\text { analyzing translation and } \\
\text { cognitive processes which } \\
\text { intermediate Italian learners } \\
\text { use to make decisions on } \\
\text { choosing appropriate words or } \\
\text { phrases, while translating. }\end{array}$ \\
\hline 2 & 2013 & $\begin{array}{l}\text { Zahra Amirian } \\
\& \\
\text { Mohamad J. } \\
\text { Baghiat }\end{array}$ & $\begin{array}{l}\text { Uncertainty and } \\
\text { Uncertainty the } \\
\text { Management: of } \\
\text { Metacognitive State of } \\
\text { Problem-Solving } \\
\text { Professional } \\
\text { (experienced) } \\
\text { Translators and Students } \\
\text { of Translation Studies }\end{array}$ & $\begin{array}{l}\text { This explanatory study } \\
\text { attempted to investigate } \\
\text { differences in Uncertainty and } \\
\text { Uncertainty Management } \\
\text { (UCM) between one } \\
\text { professional translator-a } \\
\text { person who has at least ten } \\
\text { years of experience in } \\
\text { translation activity-and non- } \\
\text { professional translators by } \\
\text { using two methodologies; } \\
\text { screen recording and Think } \\
\text { aloud protocols in retrospect. }\end{array}$ \\
\hline 3 & 2014 & $\begin{array}{l}\text { Sara Raouf } \\
\text { Khorasani, } \\
\text { Mandana } \\
\text { Yousefi }\end{array}$ & $\begin{array}{l}\text { Uncertainty and } \\
\text { Uncertainty Management } \\
\text { in EFL Translators }\end{array}$ & $\begin{array}{l}\text { This study tried to examine } \\
\text { EFL translators" uncertainty } \\
\text { and uncertainty management } \\
\text { strategies through employing } \\
\text { think aloud procedures. }\end{array}$ \\
\hline 4 & 2015 & $\begin{array}{l}\text { Karima } \\
\text { Bouziane }\end{array}$ & $\begin{array}{l}\text { Exploring the Cognitive } \\
\text { Processes of Students } \\
\text { and Professors of } \\
\text { Translation }\end{array}$ & $\begin{array}{l}\text { The aim of this research is to } \\
\text { observe and compare the } \\
\text { cognitive processes of students } \\
\text { and teachers to find out better } \\
\text { translation practices. }\end{array}$ \\
\hline 5 & 2015 & $\begin{array}{l}\text { Mohamad Javad } \\
\text { Baghiat } \\
\text { Esfahani }\end{array}$ & $\begin{array}{l}\text { Constructivism } \\
\text { Translation Training in } \\
\text { Translation Process } \\
\text { Workshops: The effect of } \\
\text { Think-aloud Protocols in } \\
\text { increasing Student } \\
\text { Uncertainty Management }\end{array}$ & $\begin{array}{l}\text { In this study think aloud } \\
\text { protocols have been used not } \\
\text { only as a data collecting } \\
\text { method but also as a technique } \\
\text { for training translators which } \\
\text { may be effectual in increasing } \\
\text { student's uncertainty } \\
\text { management and solving } \\
\text { problems. }\end{array}$ \\
\hline
\end{tabular}


$62016 \quad$ Yiqin Zou

$72017 \quad$ Samaneh

Teimooriyan,

Mandana

Yousefi

82019 Luo Fei

92019 Ryonhee Kim
2019 Mustafa

Komeili,

Azizollah

Dabaghi

Hossein Barati
Impact of Chinese Grammatical Knowledge on Translation on ThinkAloud Protocols
The research hopes to seek for a path fitting to the trend for English majors in China to improve their translation competences.

An Investigation of This study examined the Cognitive Processes of cognitive processes in Interpretation from interpretation through Persian to English employing Think-aloud Protocols (TAPs) among Iranian translators.

Evaluation of Aiming at accurately Translation Competence evaluating the translation and Thinking-aloud ability of the subjects, and Protocols looking for differences through comparative research, so as to improve translation competence of students

Use of Extralinguistic This study investigated the use Knowledge in of extralinguistic knowledge in Translation comprehension processes by analyzing data from $\mathrm{L} 2 \mathrm{~g} \mathrm{L1}$ translation, a questionnaire and a think-aloud study.

A Cognitive-oriented The study aimed at map out the exploration of cognitive processes involved in development of problem solving and provide a

\& Translation Competence: picture of development of A case Study of Iranian strategic TC and translation Translation Learners notion in translation learners

112019 Anni Holila Cognitive Processes on The aims of the study are to Pulungan, Translation Studies of describe the think aloud Masitowarni English Language protocols as one of the Siregar, Rahmad Learners assessments to explore the translation behaviours or strategies in translation and to analyze cognitive processes that occur in the mind of postgraduate students when they did the translation. This research is also necessary to know the difficulties faced by the students when conducting the process of $i t$.

Penulisan mengenai kajian terjemahan yang menggunakan TAPs dalam jadual di atas diterbitkan antara tahun 2012 hingga 2019. Jadual 3 di bawah menunjukkan bahawa jumlah penulisan untuk mengkaji proses kognitif, tingkah dan kecekapan dalam penterjemahan tidaklah sedikit. 


\section{Corak 3: Isu-Isu Lain}

Corak ketiga yang didapati daripada kajian lepas mengenai aplikasi TAPs dalam terjemahan menjurus kepada isu-isu selain corak kajian di atas. Terdapat tujuh kajian lepas yang berkaitan dengan corak kajian ketiga ini ditemukan. Jadual 4 memaparkan maklumat objektif kajian tersebut dijalankan:

Jadual 4: Isu-isu lain

\begin{tabular}{|c|c|c|c|c|c|}
\hline Bil & Tahun & Penuli & & Tajuk Kajian & Objektif Kajian \\
\hline 1 & 2013 & $\begin{array}{l}\text { Claire } \\
\text { Shih }\end{array}$ & Yi-Yi & $\begin{array}{lr}\text { Translators' } & \text { 'End- } \\
\text { Revision' } & \text { Processing } \\
\text { Patterns and } & \text { Maxims: A } \\
\text { Think-Aloud } & \text { Protocol } \\
\text { Study } & \end{array}$ & $\begin{array}{l}\text { It aims to investigate } \\
\text { translators' revision processing } \\
\text { patterns and maxims, } \\
\text { particularly after their first } \\
\text { drafts have been produced (i.e. } \\
\text { end-revision). }\end{array}$ \\
\hline 2 & 2014 & $\begin{array}{l}\text { Irina } \\
\text { Remkhe }\end{array}$ & N. & $\begin{array}{l}\text { A Comparative Analysis of } \\
\text { Written and On-sight } \\
\text { Translation within the } \\
\text { Cognitive Translation } \\
\text { Model }\end{array}$ & $\begin{array}{l}\text { The major objective of this } \\
\text { research is to provide the } \\
\text { theoretical background to } \\
\text { support the notion of the } \\
\text { cognitive translation model. It } \\
\text { also aims to gather reliable } \\
\text { evidence of the translator's } \\
\text { mental state by a comparative } \\
\text { analysis of written and on-sight } \\
\text { translation in order to verify } \\
\text { the translator's capacity for } \\
\text { problem-solving and establish } \\
\text { recognizable trends in } \\
\text { translation strategies within the } \\
\text { sphere of technical discourse. }\end{array}$ \\
\hline 3 & 2016 & $\begin{array}{l}\text { Mohsen } \\
\text { Shahrokhi }\end{array}$ & & $\begin{array}{l}\text { The Effect of Think-Aloud } \\
\text { on the Amount of } \\
\text { Translation Revision }\end{array}$ & $\begin{array}{l}\text { The current study intended to } \\
\text { check whether think-aloud had } \\
\text { any significant impact on the } \\
\text { amount of translation; and, } \\
\text { whether revision is subjected to } \\
\text { direction of language. }\end{array}$ \\
\hline 4 & 2016 & $\begin{array}{l}\text { Mohsen } \\
\text { Shahrokhi }\end{array}$ & & $\begin{array}{l}\text { The Impact of Think-aloud } \\
\text { on the Speed of } \\
\text { Translation }\end{array}$ & $\begin{array}{l}\text { This study explored the effect of } \\
\text { think-aloud as a cognitive } \\
\text { technique on the speed of texts } \\
\text { translation performed by MA } \\
\text { translation students. }\end{array}$ \\
\hline
\end{tabular}


2017 Masood Khoshsaligheh

Seeking Source Discourse Ideology by English and Persian Translators: A Comparative Think Aloud Protocol Study
The curriculum of English translation undergraduate program at Iranian universities does not formally include any course or portion of the syllabus of a course to address ideology in discourse and translation. Using think aloud protocol procedure, the present study aims at investigating the extent of this knowledge of Iranian graduates of $B A$ in English Translation

$6 \quad 2019 \quad$ Elaf Abdullah

S. Investigating

Difficulties Encountered by Iraqi's EFL Learners in Textual Translation

This study aims at investigating the causes behind the poor level in textual translation that students of English department encounter and determining college students' attitudes in Arabic and English translation.

$7 \quad 2020$

Sanjun Sun, Effects of thinking aloud on
Tian Li \& $\begin{aligned} & \text { cognitive effort in } \\ & \text { translation }\end{aligned}$

This study investigates the effects of thinking aloud on cognitive effort in translation as a function of source-text difficulty level. It does so by considering time on task, duration of different translation phases (i.e., orientation, draft, revision), cognitive effort of processing the source and target texts, and translation quality.

Kajian di dalam Jadual 4 dilihat mempunyai fokus kajian yang agak berbeza dengan corak kajian pertama dan kedua. Namun persamaan antara semua kajian ini adalah kesemuanya mengguna pakai TAPs sebagai satu atau salah satu kaedah penyelidikan untuk menyiasat subjek kajian mengenai pelbagai isu berkaitan terjemahan. Pelbagai latar isu dibincangkan dalam corak kajian ketiga ini.

\section{Perbincangan Kajian}

\section{Corak 1: Isu Berkaitan Proses Dan Strategi Terjemahan}

Berdasarkan Jadual 2 di atas, semua kajian berkisar tentang proses atau tatacara yang dilakukan oleh penterjemah semasa menterjemah teks sumber. Begitu juga dengan strategi yang dipilih oleh subjek kajian semasa menterjemah. Hal ini boleh diketahui melalui objektif kajian yang dipaparkan dalam jadual di atas. Daripada jadual ini juga, didapati bahawa sebahagian besar daripada kajian tersebut menggunakan kaedah TAPs secara khusus untuk mengkaji strategi atau cara penterjemahan yang digunakan oleh subjek kajian.

Isu yang turut dikaji dalam proses dan strategi terjemahan ialah sama ada strategi pembelajaran bahasa secara langsung dan tidak langsung digunakan semasa terjemahan sedang dilakukan, selain mengkaji masalah yang dihadapi semasa menterjemah dan bagaimana mengatasinya seperti kajian Kulwindr 
Kaur (no.3). Dalam pada itu, aspek lain yang turut dikaji ialah faktor yang mempengaruhi pemilihan strategi terjemahan seperti kajian Luo Mengyan; Zhao Yushan (no.11).

Selain itu, isu metodologi penggunaan TAPs dalam kajian terhadap terjemahan yang berorientasikan proses juga dilakukan. Kajin ini memberikan kesimpulan bahawa kaedah TAPs yang digunakan tidak memberi apa-apa implikasi negatif atau perubahan terhadap proses terjemahan, malah kaedah ini boleh dijadikan sandaran untuk menyelidiki proses terjemahan yang dilakukan oleh penterjemah dari aspek berbeza (Sun, 2011; Gheorghita, 2012).

Ini menjelaskan bahawa aplikasi TAPs mempunyai kebolehpercayaan yang tinggi dalam kalangan para penyelidik untuk menjalankan kajian mereka berkaitan proses dan strategi terjemahan.

\section{Corak 2: Isu Berkaitan Proses Kognitif, Tingkah Laku Atau Kecekapan Dalam Terjemahan}

Jika dilihat daripada objektif kajian, antara fokus penulisan dalam Jadual 3 adalah melibatkan proses kognitif untuk mengkaji aspek berbeza dalam amalan penterjemahan. Ada kajian yang dilakukan untuk menganalisis proses kognitif subjek kajian terhadap keputusan yang dibuat dan kesukaran yang dihadapi semasa proses menterjemah seperti kajian Nalan Kiziltan et al (no.1), Mustafa Komeili et al (no.10) dan Anni Holila et al (no.11). Malah, kajian untuk menyelidik proses kognitif juga dilakukan terhadap subjek kajian dalam amalan interpretasi seperti kajian Samaneh \& Mandana (no.7).

Selain itu, kajian yang mengaplikasikan kaedah TAPs turut dilakukan untuk melihat proses kognitif terhadap pelajar dan guru, bertujuan untuk membuat perbandingan antara kedua-duanya dalam proses penterjemahan seperti kreativiti, pemahaman, semakan, pendekatan dan kekangan masa, bertujuan untuk mengkaji amalan terjemahan terbaik. Memandangkan proses pemikiran tidak dapat dipantau dengan mata kasar, kaedah TAPs dilihat sesuai untuk mencapai tujuan tersebut (Bouziane, 2015).

Jadual di atas juga mengandungi beberapa kajian yang memfokuskan tingkah laku subjek kajian. Punca kelemahan subjek dalam terjemahan teks dikaji dengan menentukan tingkah laku mereka TAPs juga digunakan untuk sebagai metode untuk mengkaji tingkah laku dalam isu berkaitan keyakinan diri. Berdasarkan jadual di atas, terdapat kajian yang dilakukan untuk mengenal pasti tahap keyakinan mereka semasa menterjemah dan bagaimana mereka menguruskan ketidakyakinan diri dalam tugasan penterjemahan seperti kajian Zahra \& Mohamad J. Baghiat (no.2), dan Sara \& Mandana (no.3).

Kajian seumpama in turut dijalankan untuk mencari jalan untuk meningkatkan tahap ketidakyakinan dan masalah penyelesaian masalah yang dihadapi oleh penterjemah terutama pelajar yang mengambil jurusan terjemahan seperti kajian Mohamad Javad (no.5).

Kajian lain yang diketengahkan adalah berkaitan isu kecekapan subjek kajian. Terdapat kajian yang menjurus kepada persoalan tentang keupayaan subjek kajian dalam menterjemah dan cara menambah baik kecekapan mereka. Penulis berpendapat bahawa kecekapan juga melibatkan tahap pengetahuan penterjemah, kerana ada juga kajian yang mengkaji kecekapan subjek kajian melalui pengetahuan luar linguistik dalam usaha untuk memahami teks sumber seperti kajian oleh Ryonhee Kim (no.9).

Kajian-kajian di atas menunjukkan bahawa kaedah TAPs bukan hanya digunakan untuk mengetahui pemikiran subjek mengenai isu berkaitan strategi terjemahan sahaja. Ini membuktikan bahawa TAPs boleh digunakan untuk mengkaji pelbagai isu terjemahan dan dilihat masih menjadi pilihan ramai penyelidik bidang ini sehingga abad ke- 21 .

\section{Corak 3: Isu-Isu Lain}

Berdasarkan Jadual 4, ada beberapa isu yang menjadi fokus kajian-kajian di atas. Antaranya ialah menyelidik sama ada kaedah TAPs mempunyai impak terhadap jumlah terjemahan dan proses semakan tertakluk kepada arahan bahasa (no.3), begitu juga aspek teknikal dalam terjemahan seperti kelajuan menterjemah teks (no.4). 
Selain itu, kaedah Taps juga digunakan untuk menyelidiki faktor kelemahan pelajar dalam menterjemah teks (no.6) dan bagaimana semakan dilakukan oleh penterjemah, terutamanya selepas draf pertama teks sasaran dihasilkan (no.1).

Kaedah TAPs juga digunakan untuk mengkaji kesannya ke atas usaha kognitif semasa menterjemah yang berfungsi untuk menentukan aras kesukaran teks sumber, dengan mengambil kira pelbagai pemboleh ubah yang dikaji, antaranya tempoh masa, pelbagai fasa terjemahan (orientasi, fasa penyediaan draf, fasa semakan) dan kualiti terjemahan (no.7). Dalam kajian tersebut, kaedah TAPs memberikan natijah yang berbeza terhadap setiap pemboleh ubah yang diselidiki. Kaedah ini dilihat dapat digarap dengan baik dalam penghasilan natijah tersebut. (Sun et al, 2020).

Didapati bahawa kajian yang bertujuan untuk membina satu dasar teori untuk menyokong Model Terjemahan Kognitif turut mengguna pakai kaedah TAPs. Teori ini dibina melalui kajian perbandingan yang dilakukan antara terjemahan teks dan interpretasi (tulis-lisan), yang bertujuan untuk mengesahkan kemampuan penterjemah dalam penyelesaian masalah dan membina corak strategi terjemahan tertentu (no.2). Kajian perbandingan dalam terjemahan antara bahasa Inggeris dan bahasa Parsi yang mengguna pakai kaedah TAPs turut dijalankan untuk melihat sejauh mana subjek kajian mengetahui ideologi dalam bahasa sumber dan bagaimana mereka memindahkannya ke bahasa sasaran (no.5).

Daripada kajian-kajian dalam Jadual 4, tidak dinafikan bahawa kaedah TAPs diguna pakai secara meluas dalam mengkaji apa sahaja isu berkaitan terjemahan, iaitu isu yang boleh diselami melalui minda melalui tugasan tertentu dan dinyatakan secara lisan oleh subjek kajian.

\section{Kesimpulan}

Kaedah TAPs mula mendapat tempat dalam bidang terjemahan sejak lewat 1980-an dan seterusnya aplikasinya mulai berkembang sehingga kurun ini. Secara umumnya, kajian ini membuktikan bahawa mengaplikasikan kaedah TAPs dalam mencari jawapan dan penyelesaian kepada isu berkaitan bidang terjemahan masih relevan memandangkan kaedah ini masih menjadi pilihan ramai penyelidik. Selain itu, kaedah TAPs juga dilihat sebagai salah sat kaedah saintifik yang boleh diguna pakai untuk mengkaji apa yang berada dalam minda dan pemikiran manusia,

Melalui corak kajian yang diperoleh, didapati bahawa TAPs diguna pakai untuk mengkaji pelbagai isu dalam bidang terjemahan yang melibatkan strategi, penyelesaian masalah, membuat keputusan, perbandingan antara penterjemah, tingkah laku dan kecekapan penterjemah. Malah, TAPs juga boleh diaplikasikan untuk mengkaji ideologi penterjemah dan kreativiti dan amalan penterjemahan terbaik. Ini bermakna kaedah TAPs ini adalah bersesuaian, boleh diguna pakai dan boleh dianggap sebagai salah satu kaedah saintifik dalam bidang terjemahan, sekali gus mengetepikan kritikan sesetengah pihak bahawa kaedah ini tidak boleh mengkaji pemikiran manusia.

\section{Penghargaan}

Setinggi-tinggi penghargaan kepada pihak Pusat Pengurusan Penyelidikan USIM kerana memberi dana bagi menjalankan kajian ini melalui Geran Penyelidikan USIM (kod projek: PPPI/FPBU/0118/051000/16718)

\section{Rujukan}

Armstrong R, Waters E, Jackson N, Oliver S, Popay J, Shepherd J, Petticrew M, Anderson L, Bailie R, Brunton G, Hawe P, Kristjansson E, Naccarella L, Norris S, Pienaar E, Roberts H, Rogers W, 
Sowden A \& Thomas H. (2007). Guidelines for Systematic reviews of health promotion and public health interventions. Version 2. Australia: Melbourne University.

Bernardini, S. (2001). Think-aloud Protocols in Translation Research: Achievement, limits, future prospects. Target Online, 13(2), 241-263.

Bouziane, K. (2015)., Exploring the Cognitive Processes of Students and Professors of Translation. Arab World English Journal (AWEJ), 6(3), 81-93.

Ericsson, K. A., and Simon, H. A. (1993). Protocol Analysis: Verbal Reports as Data. Cambridge, MA: MIT Press.

Gheorghita, E. (2012). Using Think-Aloud Protocols to investigate the Translation Process Methodological Aspects. Review of the Air Force Academy, 10(3), 15-22.

Goh Sang Seong. (2013). Proses Penterjemahan, dalam Asas Terjemahan dan Interpretasi (eds. Haslina Haroon \& Hasuria Che Omar). Pulau Pinang: Penerbit Universiti Sains Malaysia.

Gurdial Singh, K.K. (2002). A think-aloud protocol of the translation process of a scientific text introduction from English to Malay. Journal of Modern Languages, 14(1).

Güss, C. D. (2018). What Is Going Through Your Mind? Thinking Aloud as a Method in CrossCultural Psychology. Frontiers in Psychology, 9, 1-11.

Hulin Zhao. (2019). A Qualitative and Quantative Analysis od Strategy of Translation Based on TAPs. International Journal of Language and Linguistics, 7(5), 182-187.

Kumar, V. (2017). The think aloud method: Some concerns addressed. Journal of Modern Languages, 15(1), 13-25.

Kussmaul, P \& Tirkkonen-Condit, S. (1995). Think-Aloud Protocol Analysis in Translation Studies. TTR: traduction, terminologie, rédaction, 8(1), 177-199.

Liberati, A., Altman, D. G., Tetzlaff, J., Mulrow, C., Gøtzsche, P. C., Ioannidis, J. P. A., Moher, D. (2009). The PRISMA statement for reporting systematic reviews and meta-analyses of studies that evaluate health care interventions: Explanation and elaboration. Journal of Clinical Epidemiology, 62, e1-134.

Noor Aina Dani \& Zaleha Abd. Rahman. (2005). Protokol pemikiran verbal dalam pemahaman bacaan teks bahasa Melayu. Jurnal Bahasa, 5(1), 136-171.

Shuhairy Norhisham. (2019). Penulisan Artikel berbentuk Sysmatic Review. Dicapai 30 Disember $2020 \mathrm{https}: / / \mathrm{www}$.pascasiswazah.com/penulisan-artikel-berbentuk-systematic-review/

Sun, S. 2011. Think-Aloud-Based Translation Process Research: Some Methodological Considerations. Meta:Translators' Journal, 56(4), 928-951.

Sun, S., Li, T., \& Zhou, X. (2020). Effects of thinking aloud on cognitive effort in translation. Linguistica Antverpiensia, New Series: Themes in Translation Studies, 19, 132-151.

Zaleha Abd Rahman. 2004. Protokol pemikiran verbal dalam pembelajaran bahasa Melayu. Tesis Master tidak diterbitkan. Fakulti Bahasa Moden dan Komunikasi. Universiti Putra Malaysia. 